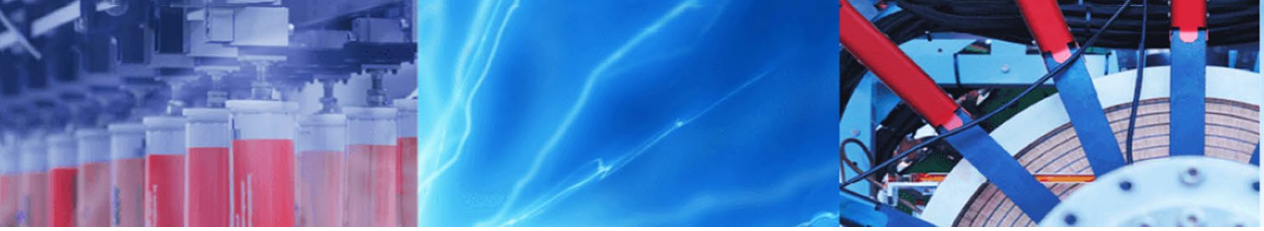

Research Article

\title{
Jet $A$ and Propane gas combustion in a turboshaft engine: performance and emissions reductions
}

\author{
Ali Hasan ${ }^{1}$. Oskar J. Haidn ${ }^{1}$
}

Received: 23 July 2020 / Accepted: 5 March 2021 / Published online: 19 March 2021

(c) The Author(s) 2021 OPEN

\begin{abstract}
The Paris Agreement has highlighted the need in reducing carbon emissions. Attempts in using lower carbon fuels such as Propane gas have seen limited success, mainly due to liquid petroleum gas tanks structural/size limitations. A compromised solution is presented, by combusting Jet A fuel with a small fraction of Propane gas. Propane gas with its relatively faster overall igniting time, expedites the combustion process. Computational fluid dynamics software was used to demonstrate this solution, with results validated against physical engine data. Jet A fuel was combusted with different Propane gas dosing fractions. Results demonstrated that depending on specific propane gas dosing fractions emission reductions in ppm are; NOx from 84 to $41, \mathrm{CO}_{2}$ from less than 18,372 to less than 15,865, escaping unburned fuels dropped from 11.4 (just Jet A) to 6.26e-2 (with a 0.2 fraction of Propane gas). Soot and CO increased, this is due to current combustion chamber air mixing design.
\end{abstract}

Keywords Turboshaft engine $\cdot$ Combustion · Jet A · Propane · Emissions · CFD

\section{Introduction}

This paper explores the reduction of emissions produced by a turboshaft aviation engine in a sustainable manner. Propane gas fuel with its lower Carbon content has been tried as an alternative aviation fuel to Jet A fuel, but has seen limited commercial success. The main reasons being the liquid petroleum gas (LPG) Propane tank's structural and size limitations. Limiting the use of liquid petroleum gas (LPG) Propane to typically smaller single engine propeller aircraft and helicopters. Experimental research work began in 1987, where LPG Propane fuel was exploited as an alternative fuel in powering a helicopter. This experimental work did not see commercial success due to the heavyweight of the pressurized LPG steel tanks [1]. Composite materials have contributed to weight reductions in fuel storage tanks and therefore Propane gas's potential as a lower carbon content fuel should be reconsidered.
However there is still a need to overcome the challenges posed by the implementation of pressurized fuel tanks into larger aircraft. Under similar conditions LPG Propane requires more fuel volume storage space than Jet $A$. In its gaseous form, Propane gas combustion has a higher adiabatic flame temperature (by approximately $0.764 \%$ ) than Jet A fuel [2]. This research considers the introduction of small fractions of Propane gas dosing in turboshaft Jet A fuel combustion engines. Gases unlike liquids do not have to go through a phase change, and therefore in general combust faster than liquid fuels. Research continues in developing efficient fuel vaporizing techniques, and improve combustion efficiency. The predominant method currently used is based on pressure-swirl atomization with a wide spray cone angle. However, given the high speed flow rates of the combusted gases, some fuel droplets may exit the combustor unburned. Since liquid fuel droplets will not have sufficient residence time to complete a liquid

Ali Hasan, alidhibiani@gmail.com; Oskar J. Haidn, oskar.haidn@tum.de | ${ }^{1}$ Faculty of Aerospace and Geodesy, Technical University of Munich, Garching, Germany. 
to gas phase change, and then burn. Several attempts were made in expediting the liquid fuel phase change, and make it ready for combustion. Such as vaporizing the liquid fuel with heat, but without success. Mainly due to the issues of thermal cracking and coke formation of fuel in vaporizer tubes. Propane with its high partial pressure vaporization of liquid, such issues do not exist.

The proposed solution is similar to what is practiced in the automotive industry [3], example in the USA and Australia. Diesel engine with Propane gas dosing and thus apply the same technique to a turboshaft engine. Since Propane gas dosing represents just a fraction of the combusted fuels, it's possible to fuel (with Propane dosing) larger aircraft for longer flights destinations. To begin with, a widely used turboshaft engine was considered, Rolls Royce 250 C20B [4]. An engine known for its applications in; small single engine aircraft, helicopters, marine and the power generation industry. The considered combustion chamber can be seen in Fig. 1.

Different fuels produce different combustion temperatures. In general; the adiabatic combustion temperature for a liquid fuel is around $2150^{\circ} \mathrm{C}$, while for natural gas it is around $2000^{\circ} \mathrm{C}$ [5]. Clarifying that these temperatures are theoretical, and not actual. Such a condition can exist in the hottest part of the flame, where the combustion chemistry is most efficient. With the assumption that a complete combustion is taking place. Also, the minimum ignition energy Emin is defined as the amount of energy needed to heat a mixture to initiate auto-ignition. Since the gaseous fuel mixture does not involve latent heat (consumed by phase changing) more of the heat energy will be available for ignition. Hence, Propane burns first and the heat released (increasing temperature) provides the energy to ignite Jet $\mathrm{A}$. Combustion temperatures can control the

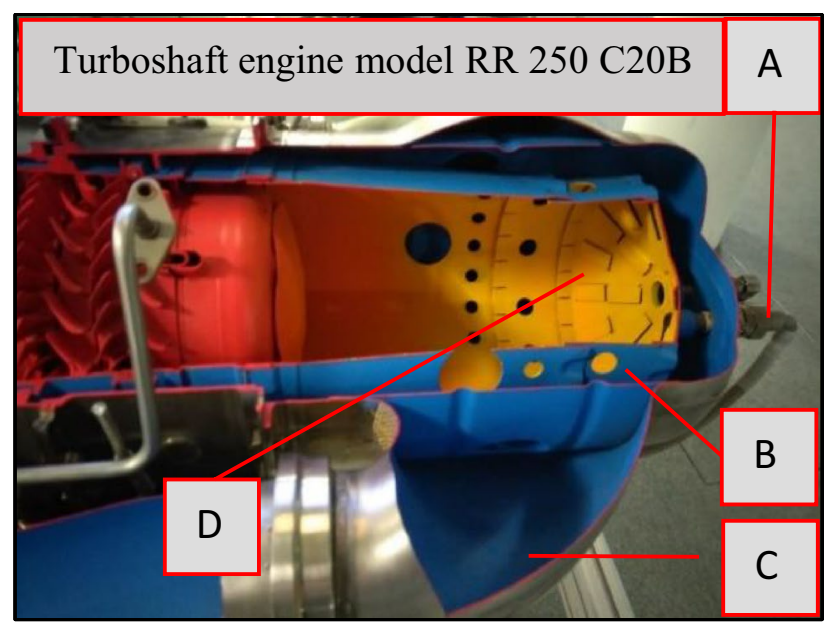

Fig. 1 Combustion chamber cut away section [1]. A=fuel inlet, $B=$ combustion can liner, $C=$ air duct and $D=$ air swirlers generation and consumption of the most reactive species, i.e. the radicals. In fact, heat is lost from the flame by radiation, convection, and even dissociation of reaction products. Which means the adiabatic flame temperature is never achieved. The actual factors of prime importance to the actual combustion temperature are; inlet temperatures of fuel and air, pressure, air/fuel ratio, and vitiation of the inlet air by products of combustion.

The main compound of soot is carbon which can existing in the diameter range of $0.01-0.02 \mu \mathrm{m}$. Almost spherical in shape, but can coalesce and form larger particles size. As an alkane Propane gas has a significant lower carbon content than Jet A fuel and thus produces less soot. Equation (1) Moss-Brooks soot model [6] was selected as it is more applicable in high hydrocarbon fuel types (Jet A fuel). Propane gas with relatively lower Carbon content than Jet $A$ and non-aromatic produces lower soot.

$$
\begin{aligned}
\frac{\mathrm{dM}}{\mathrm{dt}}= & \frac{M p C \alpha\left(\frac{\text { Xprec } P}{R T}\right)^{\prime} \exp \left\{-\frac{\mathrm{T} \alpha}{T}\right\}}{\text { Nucleation }} \\
& +\frac{C_{\gamma}\left(\frac{\text { Xsgs } P}{R T}\right) \exp \left\{-\frac{T_{\gamma}}{T}\right\}\left[(\pi \mathrm{N})^{1 / 3}\left(\frac{6 \mathrm{M}}{\rho \text { soot }}\right)^{2 / 3}\right]^{n}}{\text { SurfaceGrowth }} \\
& -\frac{C_{\text {oxid }} C_{\omega} \eta \operatorname{coll}\left(\frac{P X_{O H}}{R T}\right) \sqrt{ } T(\pi \mathrm{N})^{1 / 3}\left(\frac{6 \mathrm{M}}{\rho s o o t}\right)^{2 / 3}}{\text { Oxidation }}
\end{aligned}
$$

where $\mathrm{dM} / \mathrm{dt}$ is the rate of soot mass production $\mathrm{kg} / \mathrm{m}^{3} . \mathrm{s}$, $C_{\alpha}=54 \mathrm{~s}^{-1}$ the model constant for soot inception rate, $\mathrm{Ta}=21,000^{\circ} \mathrm{K}$ the activation temperature of soot inception, $C_{\beta}=1.0$ the model constant for coagulation rate, $C_{\gamma}=11700 \mathrm{~kg} \mathrm{~m} \mathrm{kmol}^{-1} \mathrm{~s}^{-1}$ the surface growth rate scaling factor, $T_{\gamma}=12,100^{\circ} \mathrm{K}$ the activation temperature of surface growth rate, $C_{\omega}=105.8125 \mathrm{~kg} \mathrm{~m} \mathrm{kmol}^{-10} \mathrm{~K}^{-0.5} \mathrm{~s}^{-1}$ the oxidation model constant, $n$ coll $=0.04$ the collisional efficiency parameter, Coxid $=0.015$ the oxidation rate scaling parameter, $M p=144 \mathrm{~kg} / \mathrm{kmol}$ the mass of incipient soot particle, Xsgs is the mole fraction of the participating surface growth species, Xprec is the mole fraction of soot precursor, $\rho$ soot $=1800 \mathrm{~kg} / \mathrm{m}^{3}, \mathrm{~N}$ the soot particle number density (particles $\left./ \mathrm{m}^{3}\right), \mathrm{P}=$ pressure, while constants such as; I, M, \& N can be obtained from standard text books associated with this soot model.

The numerical simulations have been performed with the ANSYS FLUENT software package [7]. For modeling combustion processes, the presumed probability density function (PDF) method has been applied. The model takes into account a statistical way in calculating variables such as; species mass fractions, temperature and density. First, the mixture composition is calculated at the grid cells and then all the mentioned variables are calculated as functions of the mixture fraction around a presumed 
probability distribution function. The PDF model can produce acceptable results for turbulent reactive flows, where convection effects due to mean and fluctuating components of velocity are dominant. Such model can be used in adiabatic and non-adiabatic scenarios [7].

In Non-Premixed combustion, the thermodynamic state of the fluid, related to the mixture fraction and the chemistry is calculated either from a tabulated steady state flamelet library or equilibrium. The turbulence chemistry interaction is described as using an assumed PDF shape [6]. The PDF as explained in the software manual exists in two forms of mathematical functions; the double density function which is most easily computed, and the $\beta$-function which represents experimental data more accurately.

\subsection{Combustion chemistry state relation}

Selecting the Equilibrium state relation means that the effects of the intermediate species and dissociation reactions are included. This produces more realistic predictions of flame temperature, and therefore it was preferred against the Eddy Dissipation model. Further discussions on this subject are included in the discussions sectionvalidating the numerical solution.

\subsection{Combustion chemistry model}

A reaction mixture is described to be in equilibrium provided the forward and reverse reactions rates are equal [7]. Equation (2) shows $\mathrm{A}, \mathrm{B}, \mathrm{S}, \& \mathrm{~T}$ the active masses, $\mathrm{k}+$ and $\mathrm{k}-$ are the rate constants. At Chemical Equilibrium condition, the two opposing reactions progress at equal rates. Therefore there is no net change in the amounts of substances involved. The equilibrium constant $\mathrm{Kc}$ is actually the subject of inputs shown to the right of the equation.

$\mathrm{K}_{\mathrm{c}}=\frac{\mathrm{k}+}{\mathrm{k}-}=\frac{\mathrm{S} \sigma \mathrm{T} \tau}{\mathrm{A} \alpha \mathrm{B} \beta}$

The Chemical Equilibrium method offers the opportunity in selecting the rich flammability limit (RFL) option [8]. In similar research involving combustion simulation of a diesel engine [9], an RFL figure of 0.1 was selected. The results were in good agreement with physical data. Noting that flammability limits vary with temperature and pressure [10]. Thus accurate settings of; boundary conditions, pressure and temperature inputs for the numerical solution are important. Therefore the software default RFL setting of 0.1 can be left as it is and then will be discussed further at the results validation stage. The RFL setting allows for partial equilibrium calculations once the mixture fraction exceeds the specified limit. Effectively increasing the efficiency of PDF calculations and allows for the by-passing of complicated equilibrium calculations performed in the fuel rich region. Such a setting is known for producing results closer to physical data than the assumption of full equilibrium. Even though the overall combustion process is lean (higher air flow than stoichiometric combustion needs), there will always be fuel rich regions. Particularly regions in the vicinity of the liquid fuel spray and individual droplets. The same explanation applies to gaseous fuels, but to a lesser extent. Since there is no liquid to a gas phase change involved. The combustion of gaseous fuels depends more on how effective the air/fuel mixing activity commences at the fuel inlet.

Ignition delay time and reaction paths are fuel-dependent. Longer ignition delay time result in a downstream shift of flame-front position and this may increase the sensitivity of the combustion chamber process to pressure fluctuations caused by heat release oscillations and may result in thermos-acoustic instability [11]. Such oscillations influence induced turbulences and can affect the way fuel(s) react with air molecules. Additionally, such oscillations destroy the boundary layer and yield a substantial increase of the local heat fluxes which may endanger the integrity of the combustor.

Equations ( $3 \mathrm{~A}$ ) and (3B) represent stoichiometric combustion of; Jet $\mathrm{A}$ (its major component) and Propane gas.

$2 \mathrm{C}_{10} \mathrm{H}_{22}+31 \mathrm{O}_{2}=20 \mathrm{CO}_{2}+22 \mathrm{H}_{2} \mathrm{O}$

$\mathrm{C}_{3} \mathrm{H}_{8}+5 \mathrm{O}_{2}=3 \mathrm{CO}_{2}+4 \mathrm{H}_{2} \mathrm{O}$

\subsection{Turbulence model}

In the shear stress transport (SST) turbulence model [12] the k-omega $(k-\omega)$ turbulence model operates at near wall conditions where it performs well at the inner boundary layer (flow in the viscous sub-layer) [13]. Then a blending function switches to the $k$-epsilon $(k-\epsilon)$ at the free stream conditions, away from the boundary wall. Where the $k-\epsilon$ turbulence model performs better (less sensitive) [14] than the $\mathrm{k}-\omega$ turbulence model. The SST turbulence model works well with adverse pressure gradients and separating flows. On the other hand it over predicts turbulence in regions with large normal strain (stagnation regions) and regions with strong acceleration. The SST model is recommended over the $k-\epsilon$ model [15]. Particularly in such applications, as it takes advantages of both worlds, the $\mathrm{k}-\omega$ and $\mathrm{k}-\epsilon$.

\subsection{Algorithm type}

Semi-Implicit Method for Pressure-Linked Equations (SIMPLE). A widely used numerical procedure used to solve the 
Navier-Stokes equations. It begins problem solving with a guess for velocity and pressure to solve for the corresponding velocities via the momentum equations. The starting guess of the pressure will not be correct, hence the obtained velocity values will not fulfil continuity. To address this, correction factors for velocity and pressure are introduced. Transport equations for these factors are proposed and solved, producing amended velocities and

Table 1 Data for $\mathrm{CO}_{2}$ emissions and Energy Density, based on producing $293.1 \mathrm{kWh}$ of energy from burning the following hydrocarbon fuels

\begin{tabular}{lll}
\hline Fuel & $\mathrm{CO}_{2}, \mathrm{~kg}$ & Energy density, $\mathrm{MJ} / \mathrm{kg}$ \\
\hline Kerosene & 72.3 & 43 \\
Decane $\left(\mathrm{C}_{10} \mathrm{H}_{22}\right)$ & - & 47.6 \\
Benzene $\left(\mathrm{C}_{6} \mathrm{H}_{6}\right)$ & - & 43 \\
Hexane $\left(\mathrm{C}_{6} \mathrm{H}_{14}\right)$ & - & 48.3 \\
Propane $\left(\mathrm{C}_{3} \mathrm{H}_{8}\right)$ & 63.2 & 49 \\
\hline
\end{tabular}

Source of data [1] pressure values. The remaining transport equations, e.g. for different scalars, can then be solved. A check for convergence is then made and the method is repeated until convergence is reached [15].

Research begins by CFD modeling of the engine's combustion can liner with Jet A fuel combustion. Then validate results against the engine's physical data. Once the CFD model's integrity is established, then the effects of dosing Jet A fuel with Propane gas fuel were researched. Similar research work on the same engine was recently carried out, but with the difference of injecting superheated steam rather than Propane gas dosing [1].

\section{Materials}

Figure 1 shows a close up view of the considered turboshaft engine, RR 250 C20B. Data in Table 1 shows typical fuel $\mathrm{CO}_{2}$ emissions and energy density based on combustion processes generating $293.1 \mathrm{kWh}$ [1]. Table 2 shows information for peak engine operating conditions, such

Table 2 Engine physical operational details-model RR 250 C20B based on Jet A fuel only

\begin{tabular}{|c|c|c|}
\hline Item & Detail & Remarks \\
\hline Engine weight & $71.8 \mathrm{~kg}$ & \\
\hline Power/weight ratio & $2.7: 1$ & \\
\hline Air flow & $1.57 \mathrm{~kg} / \mathrm{s}$ & $\begin{array}{l}\text { Approximately } 20 \text { to } 25 \% \text { of the air supply is required to } \\
\text { burn the fuel. The remainder is used for cooling the } \\
\text { combustion can liner wall }\end{array}$ \\
\hline Pressure ratio & 7.1:1 & \\
\hline Compressor stages & 6 & Begins in stage 1 near the air intake \\
\hline Power output shaft & $6,016 \mathrm{rpm}$ & 7 \\
\hline Gas producer shaft & $50,970 \mathrm{rpm}$ & At $100 \%$ operational speed \\
\hline Power turbine rotor & $33,290 \mathrm{rpm}$ & \rfloor \\
\hline Fuel types & $\begin{array}{l}\text { ASTM-1665 Jet } A \text {, } \\
\text { A1, \& B }\end{array}$ & \\
\hline Fuel flow rate & $0.035 \mathrm{~kg} / \mathrm{s}$ & $\begin{array}{l}\text { The considered figures are at takeoff conditions at sea } \\
\text { level, altitude } 0 \mathrm{~m} \text {. Standard day conditions at an } \\
\text { approximate temperature of } 20^{\circ} \mathrm{C}\end{array}$ \\
\hline $\begin{array}{l}\text { Air temperature at the } \\
\text { compressor's outlet }\end{array}$ & $260^{\circ} \mathrm{C}$ & $\begin{array}{l}\text { This is the temperature of air entering the combustion } \\
\text { chamber }\end{array}$ \\
\hline $\begin{array}{l}\text { Compressor air intake } \\
\text { temperature }\end{array}$ & $15^{\circ} \mathrm{C}$ & $\begin{array}{l}\text { NACA standard day conditions - static sea level conditions } \\
\text { at } 1 \text { bar, } 0 \% \text { relative humidity and ram. }\end{array}$ \\
\hline Turbine inlet temperature & $593-1,038^{\circ} \mathrm{C}$ & \\
\hline Turbine pressure outlet & 4.74 bar & Gauge pressure \\
\hline $\mathrm{CO}$ & 105 ppm & Based on above fuel flow rates and a fuel sulfur content of \\
\hline NOx & $12 \mathrm{ppm}$ & $0.057 \%$ \\
\hline $\mathrm{SO}_{2}$ & $12 \mathrm{ppm}$ & \\
\hline Particulates matter (soot) & $2.3 \mathrm{e}-5 \mathrm{~kg} / \mathrm{s}$ & \\
\hline
\end{tabular}

Source of data $[1,4,16]$ 
as a helicopter takeoff scenario $[1,4,16]$. As fuel enters at ' $A$ ', the air swirlers increase turbulence thus better fuel/air missing. The radial air inlets provide further dilation and turbulence for better combustion results. The indicated air inlets also provide a cooling air layer for the can liner inner wall. Shielding the can liner inner wall from excessive heat.

Information used in specifying boundary conditions in this research were extracted from engine's physical data shown in Table 2.

Covering engine physical data on; air and fuel, and outputs; exhaust emissions, temperature and pressure.

\section{Method}

Figure 2 shows the location of the combustion can liner shown in Fig. 2. The next step involves generating a model for the combustion can liner as shown in Fig. 3. CFD tools were used to generate results for the proposed combustion method. An acceptable level of CFD expertise is necessary.

To ensure an accurate numerical solution, boundary conditions had to be accurately prepared. Physical combustion can liner measurements were made to ensure wall boundary accuracies and then modeled in 3D. Figure 3 image shows labeled outlet, and air inlets with dimensions shown in dashed boxes. Fuel inlets are separate (NonPremixed) were labeled as shown. Notice the opposing directions of the air swirlers, maximizing turbulences for better air/fuel mixing. Standard procedures in mesh preparations were followed; (a) avoiding non-orthogonal cells close to boundary walls. The angle between the grid lines and boundary walls should be close to $90^{\circ}$; (b) avoiding highly skewed cells, angles should be kept between $40^{\circ}$ and $140^{\circ}$. The maximum Skewness should be less than 0.95 and the average below 0.33 [15]. (c) higher-order hexahedra, prisms, and quadrilaterals are recommended for their accuracy. (d) if this is not possible as in (c), then aim for a high order hexahedra-dominant or quadrilateral-dominant mesh. (e) low-order; tetrahedral/triangles/prisms/ hexahedral/ quadrilaterals were avoided for their inferior accuracy compared with high order types [17]. Once mesh generation was completed, quality checks can now be made. The mesh details showed the following; number of cells in the combustion can liner 479,349. Mesh Metrics, the Jacobian Ratio (Corner Nodes) [7] figures; minimum 0.20 , maximum 1.00 , average 0.83 , and standard deviation $9.7 \mathrm{e}-2$. The low standard deviation figure indicates that most elements are nearer the average Jacobian Ratio of 0.83 (closer to 1), indicating a good mesh. As an insurance while checking the mesh quality, select (in the Details of Mesh menu) Check Mesh Quality [7] > "Yes, Errors and

Fig. 2 A turboshaft engine schematic showing the considered operational data, obtained from Table 2
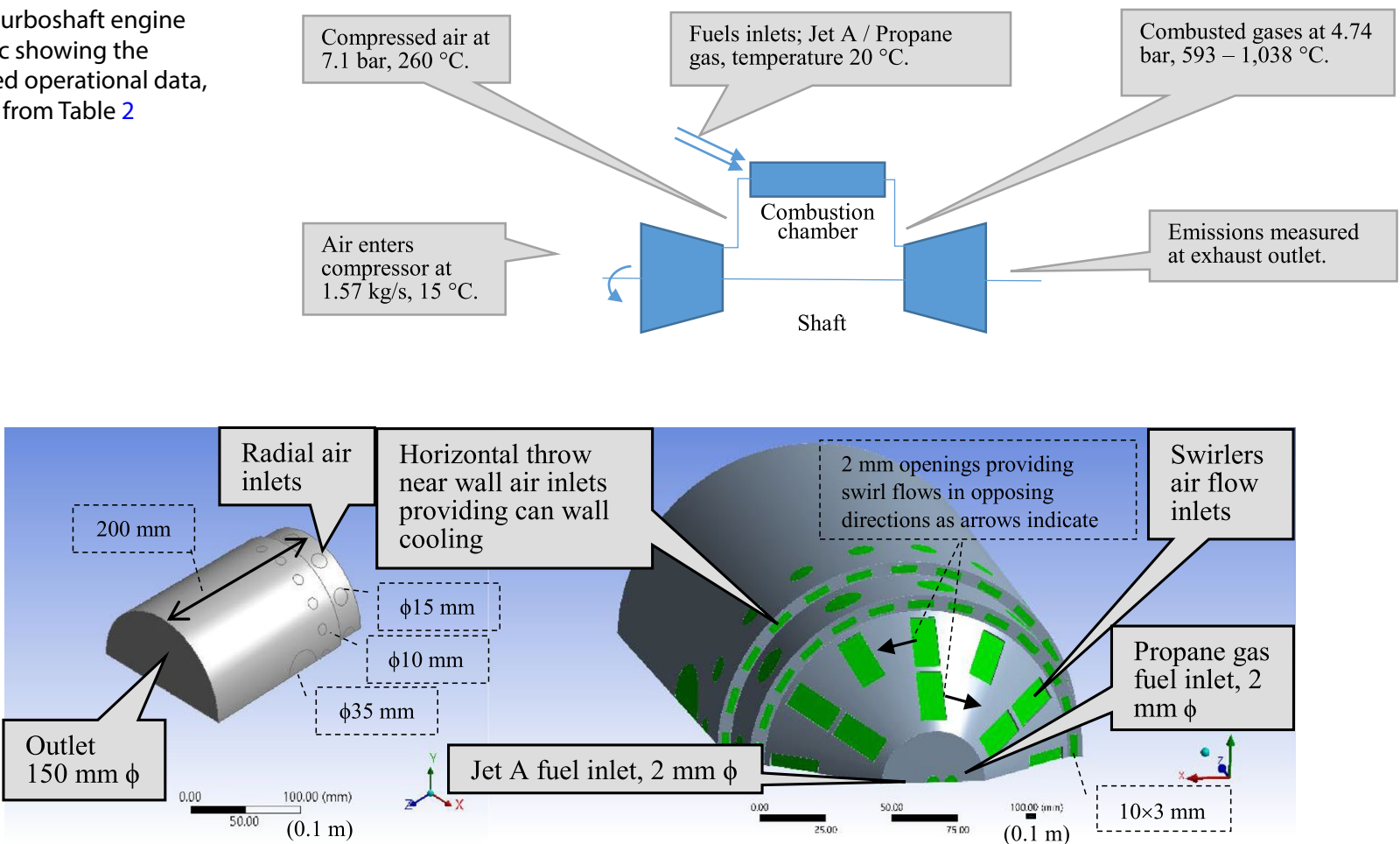

Fig. 3 Combustor can liner section, pre-processor views. Top left image shows front view, lower left image shows rear view. Right image shows angled rear view highlighting inlet boundary conditions. $\phi=$ diameter 
Warnings". The Target Skewness value was set at 0.9, lower than the above shown recommended maximum. The software has the capability in reporting and errors/ warnings, by initiating the Check Mesh Quality option in the mesh module. No warnings/errors were reported on the generated mesh, and therefore continued to the setting up stage. Fuel streams and air inlets were assigned as indicated in Figs. 2 and 3. The following information was entered in the Non-Premixed modeling in the Species menu. For the first fuel stream inlet; a typical Jet $A$ fuel mass composition; $72.7 \%$ decane, $9.1 \%$ hexane and $18.2 \%$ benzene [18]. Other general information judged to be insignificant and therefore omitted, these are; special additives such as corrosion inhibitor, anti-fouling \& static compounds are in the range $1-2 \%$. For the second inlet fuel stream; Propane gas was selected, and then the remaining oxidizing fluid Oxygen and Nitrogen as per software default settings. See Fig. 3 for inlets boundary conditions. The Chemical Equilibrium combustion chemistry model was selected. The RFL was kept at default value of 0.1. The PDF table can now be generated. Solver settings; Pressure based known for its robustness in moderate compressibility applications, and SIMPLE algorithm was used to link the velocity field with the pressure distribution within the model [19]. For Spatial Discretization; momentum and energy equations were assigned with first and second order respectively. The SST turbulence model was selected. Pointing out that the $k-\omega$ part of SST is capable of predicting the law of the wall in the viscous sub-layer, and removes the need for wall functions [17]. However a good mesh near boundary walls is important, therefore inflated mesh layers were assigned to the combustion can liner boundary walls. Which is 5 inflated layers as per default setting. The suitability of these selections will be discussed once results are available for validation. Convergence target was set for a Residual History 1e-3. Processing was then run for the different fuel inlet breakdowns shown in Table 1. Information entered for the inlets and outlets boundary conditions shown in Figs. 2 and 3, can be seen in Table 2 for; air, fuel, pressure, and temperature inputs. Turbulence intensity at inlets were left at default, which is low as turbulence burley begins at fluid inlets. At outlet turbulence intensity was left at default with thermofluid properties assigned. The Moss-Brooks soot model was selected, one step. Noting that this model is based on carbon formation, and will not give general particles (of any type) in exhaust. Numerical solutions were generated for the following Propane gas fuel dosing fractions; $0,0.05,0.1,0.15$ and 0.2 .

Propane gas dosing was considered in this research to expedite the completion of the combustion process and lower emissions. However, there is no reason why not to consider any other fuel for dosing, and expedite the combustion of Jet A fuel. In general when considering other dosing fuels, the following information needs to be considered with regards to the fuel ignition delay time. Fuel ignition delay time is higher with lower fuel density, kinematic viscosity and fuel/air surface tension. Also longer ignition delay time were observed with component fuels of higher fuel volatility as measured by boiling point and vapor pressure $[20,21]$. Reflecting this information on the considered Propane gas fuel, at $15^{\circ} \mathrm{C}$; Propane gas density $2.42 \mathrm{~kg} / \mathrm{m}^{3}$ [22] is lower than Jet A fuel liquid density [23] $813 \mathrm{~kg} / \mathrm{m}^{3}$ and therefore longer ignition delay time. On the other hand, Propane gas's kinematic viscosity [22] $4.2 \mathrm{~mm}^{2} / \mathrm{s}$ is higher than Jet A kinematic viscosity [23] $2.8 \mathrm{~mm}^{2} / \mathrm{s}$ and therefor lower ignition delay time (faster ignition). Such information illustrates how a number of factors can influence the ignition delay time. A small dosing of a low ignition delay time fuel can expedite the combustion completion process of Jet A fuel.

\section{Results and discussions}

Results are tabulated in Tables 3, 4, and 5, associated graphs follow. Detailed discussions follows later.

Table 3 shows results for Jet A fuel (only) and engine physical operational data, for validation purposes. Percentage differences between CFD results and physical data are tabulated. The CFD results were judged to be reasonably accurate and therefore can continue researching. Cross grid independence check wasn't deemed to be necessary, since the validation process provides an overall level of accuracy. Percentage differences between CFD results and physical data for pressure and temperature are 2.1 and $1.0 \%$ respectively. The validation of $\mathrm{SOx}$ results have shown a percentage difference of $15 \%$ between CFD results and physical data.. The SOx CFD post-processing results were only considered for Jet $A$ fuel, and just for validating purposes. The reason for this decision is that,

Table 3 Validated results - CFD v Physical engine operational data

\begin{tabular}{llll}
\hline $\begin{array}{l}\text { Validating at } \\
\text { outlet }\end{array}$ & CFD results & $\begin{array}{l}\text { Engine physical } \\
\text { data }\end{array}$ & $\begin{array}{l}\text { Percentage } \\
\text { difference, \% }\end{array}$ \\
\hline Pressure, bar & 4.80 & 4.74 & 2.1 \\
Temperature, ${ }^{\circ} \mathrm{C}$ & 587.5 & $593-1038$ & 1.0 \\
NOx & $84 \mathrm{ppm}$ & $89 \mathrm{ppm}$ & 6.0 \\
$\mathrm{SOx}$ & $10.4 \mathrm{ppm}$ & $12 \mathrm{ppm}$ & 15.0 \\
$\mathrm{CO}$ & $<665 \mathrm{ppm}$ & $105 \mathrm{ppm}$ & \\
$\mathrm{CO}_{2}$ & - & - & \\
$\mathrm{Soot}$ & $0.96 \mathrm{~kg} /$ & $2.3 \mathrm{e}-5 \mathrm{~kg} / \mathrm{s}$ & \\
& $\mathrm{m}^{3}-\mathrm{s} \approx$ & particles & \\
& $(0.08 \mathrm{~kg} / \mathrm{s})$ & & \\
\hline
\end{tabular}

Source of data [1] 
Table 4 Fuel fractions breakdowns at the two fuel inlets $v$ unburned fuels at the outlet

\begin{tabular}{lllllll}
\hline $\begin{array}{l}\text { Jet A/Propane gas } \\
\text { fractions }\end{array}$ & $1 / 0$ & $0.95 / 0.05$ & $0.9 / 0.1$ & $0.85 / 0.15$ & $0.8 / 0.2$ & $0 / 1$ \\
\hline Propane gas & 0 & $2.85 \mathrm{e}-3$ & $7.86 \mathrm{e}-3$ & $14.63 \mathrm{e}-3$ & $22.61 \mathrm{e}-3$ & 490.447 \\
Jet A (ppm) & 11.4 & $7.7 \mathrm{e}-2$ & $6.29 \mathrm{e}-2$ & $5.20 \mathrm{e}-2$ & $4.00 \mathrm{e}-2$ & 0 \\
Combined & 11.4 & $7.99 \mathrm{e}-2$ & $7.08 \mathrm{e}-2$ & $6.66 \mathrm{e}-2$ & $6.26 \mathrm{e}-2$ & 490.447 \\
\hline
\end{tabular}

Table 5 Combustion results

\begin{tabular}{|c|c|c|c|c|c|c|c|c|c|}
\hline $\begin{array}{l}\text { Jet } A / \text { Propane gas } \\
\text { dosing in fractions }\end{array}$ & $\begin{array}{l}\text { Energy theory, } \\
\mathrm{MJ} / \mathrm{kg}\end{array}$ & $\begin{array}{l}\text { Energy out } \\
\text { CFD, MJ/kg }\end{array}$ & Tout, ${ }^{\circ} \mathrm{C}$ & Pout, bar & NOx & $\mathrm{SO}_{2}$ & CO ppm & $\mathrm{CO}_{2}$ & Soot \\
\hline $1.0 / 0.0$ & 1.637 & 1.611 & 587.5 & 4.80 & 84 & 10.4 & $<665$ & $<18,372$ & 4.96 \\
\hline $0.95 / 0.05$ & 1.642 & 1.605 & 539 & 5.40 & 33 & - & $<9560$ & $<18,364$ & 6.02 \\
\hline $0.9 / 0.1$ & 1.647 & 1.607 & 535 & 5.48 & 53 & - & $<10,200$ & $<18,037$ & 5.16 \\
\hline $0.85 / 0.15$ & 1.652 & 1.608 & 532 & 5.50 & 41 & - & $<10,500$ & $<17,804$ & 6.2 \\
\hline $0.8 / 0.2$ & 1.657 & 1.61 & 544 & 5.55 & 43 & - & $<9220$ & $<17,447$ & 9.22 \\
\hline $0 / 1.0$ & 1.736 & 1.71 & 634 & 5.75 & 84 & - & $<6120$ & $<15,865$ & 0 \\
\hline
\end{tabular}

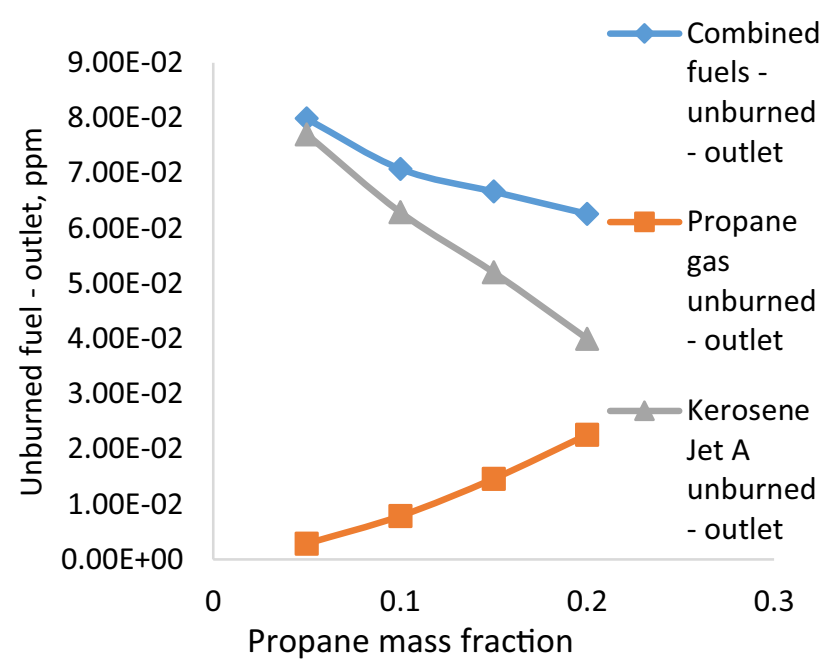

Fig. 4 Unburned fuels-Jet A with Propane gas dosing mass fractions shown. Plot begins at a Propane gas dosing mass fraction of 0.05 and ends at 0.2 , for better illustration. See Tables 3 and 4

SOx contents can vary depending on fuel type and supplier. Whereas $\mathrm{NOx}, \mathrm{CO}_{2}$ and soot emissions are more controlled by the combustion process, rather than just the source of fuel supplier. For NOx results a difference of $6 \%$ was observed between CFD results and physical data, thus results were judged to be exceptionally accurate. The CO CFD results were expressed as maximum levels at the outlet, and increased as Propane gas dosing fractions increased, The $\mathrm{CO}_{2}$ physical data were not available, and therefore cannot validate against.

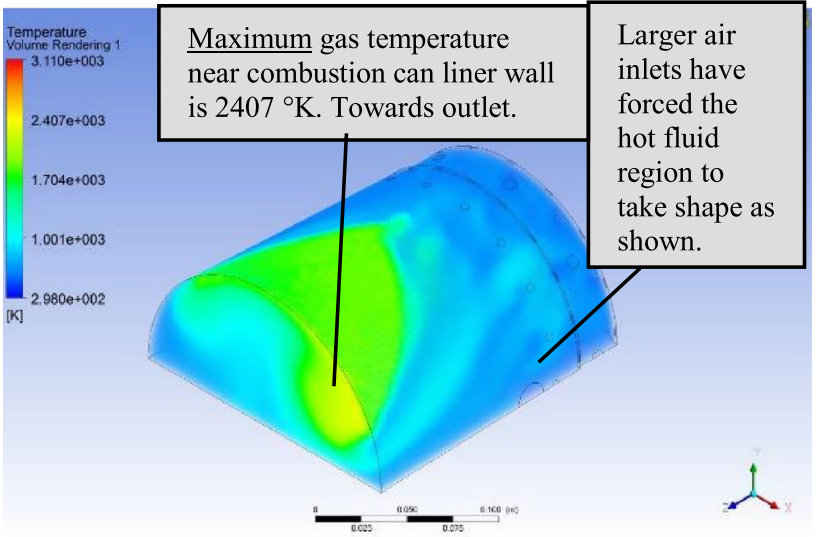

$(0.1 \mathrm{~m})$

Fig. 5 Angled symmetrical section view of combustion can liner. CFD temperature volume rendering

Table 4 results show an improvements instigated by Propane gas's faster overall ignition time. Indicating an overall reduction in unburned fuels escaping, see Fig. 4.

Table 5 showed a slightly lower energy level of $1.605 \mathrm{MJ} / \mathrm{kg}$ at a mass fraction of 0.05 in Propane gas dosing. Temperature dropped to $532{ }^{\circ} \mathrm{C}$ at a mass of 0.15 in Propane gas dosing. Then increased to $634{ }^{\circ} \mathrm{C}$ at a fraction of 1.0, which is Propane gas combustion only. A temperature volume rendering can be seen in Fig. 5 for Jet $A$ fuel only. The pressure increases are inevitable, due to the corresponding temperature increases.

The NOx levels increased as temperature increased giving 84 ppm at Propane and just Propane gas. Low NOx at $33 \mathrm{ppm}$ with a mass fraction of 0.05 Propane gas. The 


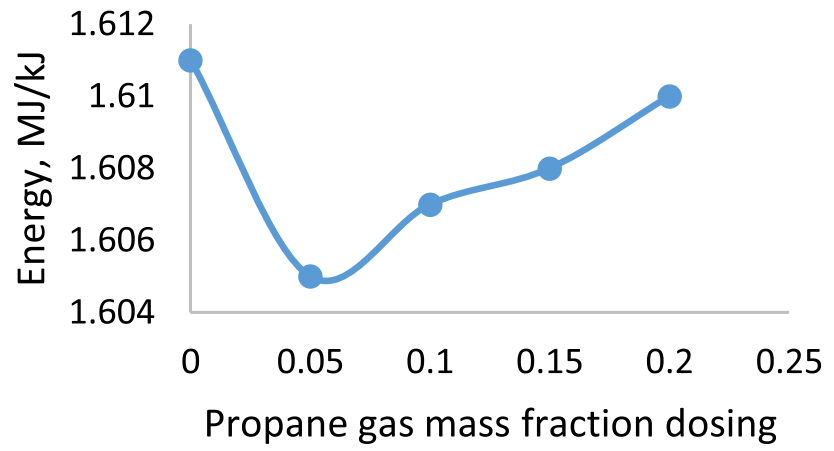

Fig. 6 Energy v Propane gas dosing fractions

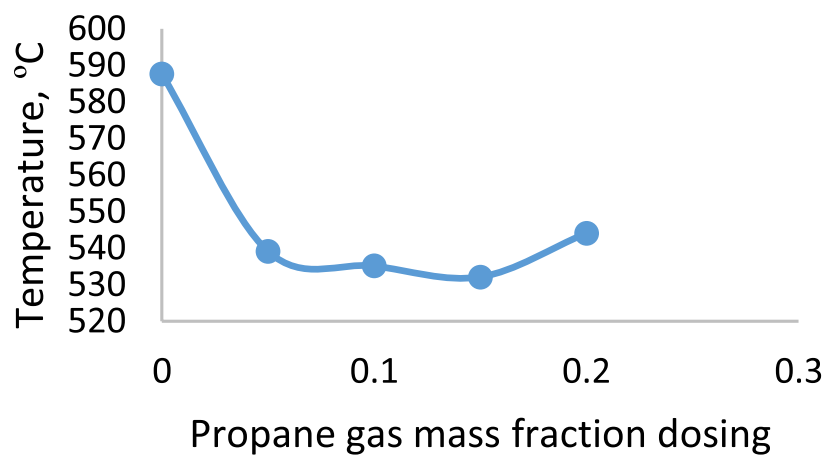

Fig. 7 Temperature v Propane gas dosing fractions

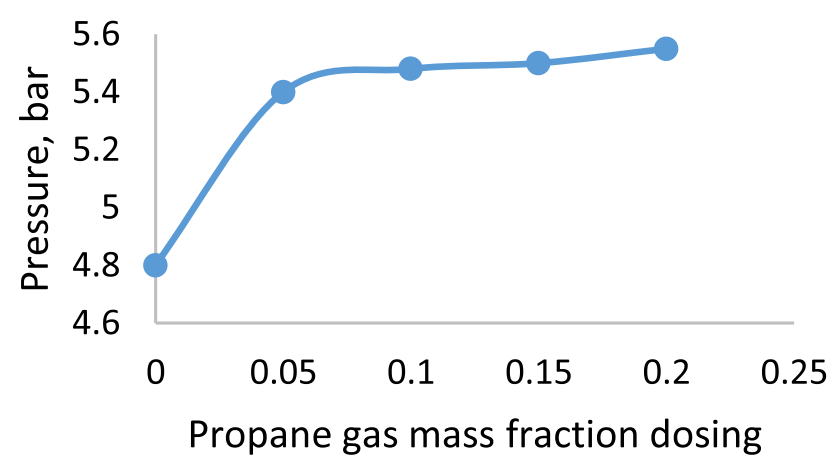

Fig. 8 Pressure v Propane gas dosing fractions

CO levels increased as Propane mass dosing fractions increased, then a slight drop in CO levels was observed at a mass dosing faction of 1.0 (Propane gas only). The level of $\mathrm{CO}_{2}$ dropped as Propane mass dosing fractions increased, and lowest level $<15,865 \mathrm{ppm}$ at a mass fraction of 1.0 (Propane gas only). Soot levels showed slight increases, with Propane mass dosing fraction, but $0 \mathrm{ppm}$ at Propane gas combustion only. The briefly discussed results are shown in Figs. 5, 6, 7, 8, 9, 10 and 11, in depth discussions follows.

SN Applied Sciences

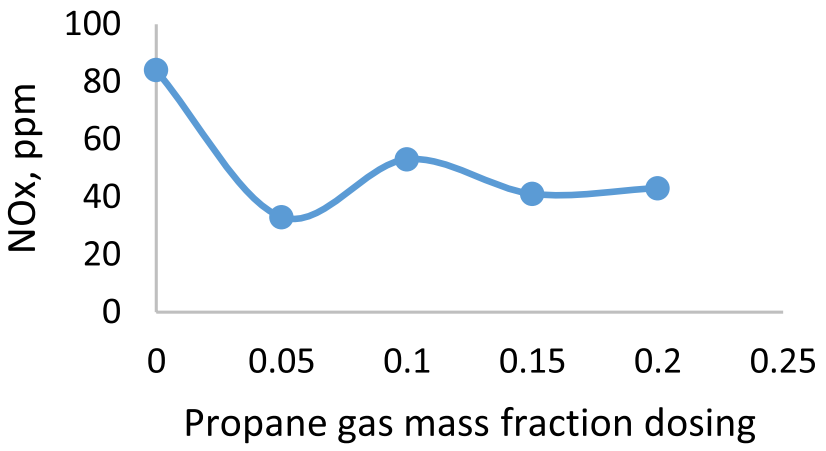

Fig. 9 NOx v Propane gas dosing fractions

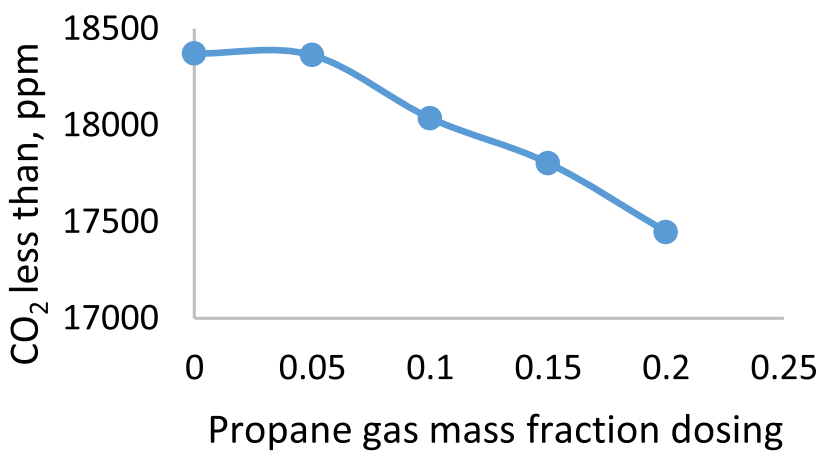

Fig. $10 \mathrm{CO}_{2} v$ Propane gas dosing fractions

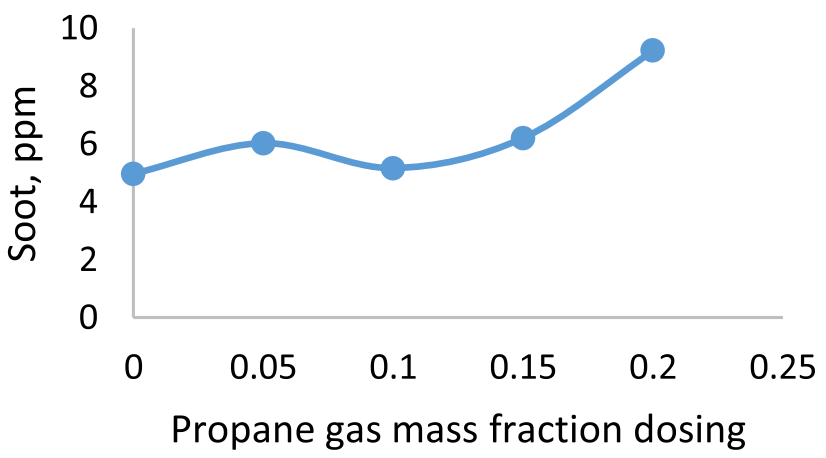

Fig. 11 Soot v Propane gas dosing fractions

The energy output showed a slight decreases in Fig. 6, this is because Propane gas has a lower density. Hence a higher volumetric flow rate. Which will absorb heat energy from within the combustion can. As Propane gas mass fraction increase energy output increases due to its higher energy density. With Propane gas's faster overall ignition, less unburned fuel was observed escaping at the outlet.

The engine cycle efficiency has now the following changes. Notice how increasing $T_{3}$ caused the combustion pressure output to increase. The increase in $\mathrm{T}_{3}$ (due to Propane gas higher adiabatic temperature) is an additional 
factor in improving power output when weighed against the given emissions in Table 5.

$\eta=\frac{(\mathrm{T} 3-\mathrm{T} 4)-(\mathrm{T} 2-\mathrm{T} 1)}{(\mathrm{T} 3-\mathrm{T} 2)}$

Increases in $T_{3}$, the combustion can outlet temperatures in Eq. (4), are clear. Effectively increasing heat input $\left(T_{3}-T_{2}\right)$ and turbine work output $\left(T_{3}-T_{4}\right)$. As Propane gas dosing fractions increased, NOx figures decreased, and then increased again with Propane fuel gas only. However not as high as when burning just Jet A fuel. Table 5 shows the effects of temperature on thermal NOx formation. One could ask, what is the reason behind the lower NOx figures? While the overall combustion temperatures caused by Propane gas dosing is actually higher than just Jet A combustion? The answer is Propane gas molecules are able to immediately interact with air and combust. Whereas in a liquid fuel, a phase change takes place first (liquid to gas) and only then vapor and air molecules can combust. In such a process rich flame regions are created with higher flame temperature zones, subsequently leading to thermal NOx formations. Combustion pressure oscillations play a role and depending on what fraction fuel combinations are involved. A phase shift in pressure oscillations can minimize vibrations, by keeping pressure oscillations out of phase. A tradeoff is required between higher $\mathrm{T}_{3}$ effecting (caused by Propane gas combustion) Eq. (4) and more compressor air directed to the combustion can liner wall cooling needs.

The $\mathrm{CO}_{2}$ results in Table 5 did show a decrease against an increase in Propane gas dosing fractions. Which is expected, due to; Propane gas's lower carbon content, and faster overall ignition time introduced by Propane gas. The CFD soot results are carbon based, and cannot be validated against available physical data, which refers to particles. Particles in exhaust could be based on; any impurities in fuel, NOx, SOx, and Volatile Organic Compounds (VOCs).

A quick glance at Eq. (1) shows if oxidation increases than $\mathrm{dM} / \mathrm{dt}$ decreases (soot). Note the same occurred with $\mathrm{CO}$, increasing as soot increases. Pointing to lack of oxidation. Therefore more air will have to be directed near the fuel inlets locations (the flame's root). Another way of improving this; safe partial premixing of Propane gas \& air can be done. Such that the lower flammability limit (LFL) is not exceeded. Keeping the partial premix below the LFL will prevent the flame moving upstream the fuel lines, but just sufficient partial premixing with air to mitigate further oxidation once the mixture enters the combustion can liner. Practically, the rate of soot forming tends to be influenced by the physical processes of at optimization and air-fuel mixing rather than chemical kinetics. Propane gas with its higher hydrogen to carbon ratio compared to Jet $A$, is a non-aromatic fuel and therefore will produce less $\mathrm{CO}_{2}$ and soot. Since more of the combustion heat is generated by hydrogen rather than a carbon reaction. Heat produced by the engine can warm-up the Propane fuel gas pipe line near the combustion chamber. This enhances phase change (liquid to gas if LPG is the source fuel) before entering the combustion chamber. Propane gas dosing practically changes the combustion process due; to reduced localized high temperature flame zones, faster overall ignition time (less fuel escaping), and more energy available as in Table 5 with propane gas only. Results therefore point to the possibility of using LPG Propane gas tanks with their structural limitations (sizing) in powering larger aircraft/long distance flights. On the basis of Propane gas dosing in small fractions while Jet A remaining as the primary fuel. Thus avoiding the challenges associated with an aircraft carrying large pressurized liquefied fuel gas tanks, when switching completely from liquid Jet $A$ to a gaseous fuel. Switching between Jet A fuel only and duel fuel (Propane dosing) combustion can easily be done. Current practices in aircraft liquid fuel tanks do use fuel shut off valves, and the same can be done with fuel gas lines.

Finally but not least, the CFD settings were found exceptionally accurate when validated. The Equilibrium combustion chemistry With 1 step chemical reaction results were found to be acceptable when validated in Table 3. This can be explained due to the fast flow of exhaust gases where a 1 step chemical reaction is known for its reliability and fast computing. Whereas a CHEMKIN 2 step chemical reaction is known for complex reactions, therefore was not selected. Validated results indicated that the 1 step chemical reaction was sufficient. It can be said that despite the following disadvantages in using LPG Propane:-LPG Propane's higher volume storage space (compared to than Jet A), pressurized tank's structural limitations, and Propane gas's higher adiabatic flame temperature; such disadvantages can be justified. Considering the advantages gained in emissions reductions. Other justifications; Propane gas exists in abundance worldwide and doesn't need significant additives and production processing. Thus proposing a gradual transition towards a lower carbon content fuel, Propane gas rather than Jet A. Contributing to mitigate the challenges presented by the Paris Agreement.

\section{Conclusion}

Burning a small amount of Propane gas with Jet A fuel in the combustion chamber can contribute to a reduction in emissions and improved power output, see Tables 4 and 5. Thus initiating a gradual transition from Jet A fuel 
to Propane gas fuel in a practical and economic way. This can be achieved by burning just a small fraction of Propane gas, while Jet A remains to be the primary source of combustion fuel. Propane gas exists in abundance and contains less carbon than Jet A fuel, see Table 1. Proposed solution offers a gradual reduction in carbon emissions. Addressing the Paris Agreement's carbon reduction plans and in general the global demand for reductions in aviation emissions.

Results have shown a drop in the overall unburned fuels escaping at the combustion can liner outlet. Dropping from 11.4 to $6.26 \mathrm{e}-2 \mathrm{ppm}$ by dosing a fraction of 0.2 of Propane gas, NOx reduced from 84 to $41 \mathrm{ppm}$ at a dosing fraction of 0.15 Propane gas, $\mathrm{CO}_{2}$ dropped as Propane gas fractions increased, levels dropped from $<18,372$ to $<15,865$ ppm by just burning Propane gas, and soot increased from 4.96 to 9.22 ppm at a dosing fraction of 0.2 Propane gas. However with just Propane gas combustion, soot level was at 0 ppm, as is known Propane gas doesn't produce soot when correctly burned.

The relatively high unburned Propane gas escaping (Propane combustion only) was not expected. This can be due to the current combustion can liner design. Since it was not designed for gaseous fuel combustion and can be redesigned with suitable gaseous fuels inlet with air/ fuel gas premixing.

CFD settings were found to be exceptionally accurate when validated in Table 3. Percentage differences were from 1 to $6 \%$ for various measured parameters. With the exception of SOx CFD v engine operational data showed a difference of $15 \%$. A relatively high percentage difference, however SOx production depends on the quality of fuel supply, and can vary.

Main limitation observed was the academic software version with limited number of cells. Though results showed exceptional accuracy when validated. It is recommended to repeat this research with the full software version with different turbulence models for comparison. The other limitation was that the combustion can liner fuel inlets were not designed for Propane gas dosing. This can be improved by redesigning this section of the combustion can liner and then further research and development can be done.

Acknowledgments Thanks to my family for their support.

\section{Declaration}

Conflict of interest The author(s) declared no potential conflicts of interest with respect to the research, authorship, and/or publication of this article.

Open Access This article is licensed under a Creative Commons Attribution 4.0 International License, which permits use, sharing, adaptation, distribution and reproduction in any medium or format, as long as you give appropriate credit to the original author(s) and the source, provide a link to the Creative Commons licence, and indicate if changes were made. The images or other third party material in this article are included in the article's Creative Commons licence, unless indicated otherwise in a credit line to the material. If material is not included in the article's Creative Commons licence and your intended use is not permitted by statutory regulation or exceeds the permitted use, you will need to obtain permission directly from the copyright holder. To view a copy of this licence, visit http://creativeco mmons.org/licenses/by/4.0/.

\section{References}

1. Hasan A, Haidn OJ (2021) Combustion of kerosene jet A fuel and superheated steam injection in an aviation turboshaft engine: improving power output and reducing emissions. J Inst Eng India Ser C. https://doi.org/10.1007/s40032-020-00643-x

2. Koc I (2015) The use of liquefied petroleum gas (LPG) and natural gas in gas turbine engines. Adv Energy Res 3(1):31

3. Ashok B, Ramesh Kumar C (2015) LPG diesel dual fuel enginea critical review. Alex Eng J. https://doi.org/10.1016/j.aej.2015. 03.002

4. RR 250 C20B Training Manual (1996) Rolls Royce Customer Training Department, RR Corporation, Indianapolis USA. Sections; Basic engine specifications, Installation design, and Fuel flow at takeoff chart.

5. Meher-Homji CB, Zachary J, Bromley AF (2010). Gas turbine fuels-system design, combustion and operability. In: Proceedings of the thirty-ninth turbomachinery symposium, Texas A\&M University, p 155

6. ANSYS FLUENT 12.0 User's Guide (2009) Modelling Non-Premixed Combustion. ANSYS Inc. USA. Sections 23.3.1 and 16.2

7. ANSYS FLUENT ${ }^{R}$ Academic software version R19.3. ANSYS Inc. USA

8. Pope SB (1997) Turbulence combustion modeling: fluctuations and chemistry. In: Roy GD, Frolov SM, Givi P (eds) Advanced computation and analysis of combustion. ENAS Publishers, Moscow, pp 310-320 (ISBN 5-89055-006-3)

9. Atkins P, De-Paula J (2006) Atkins' physical chemistry, 8th edn. Oxford University Press, Oxford, pp 200-202 (ISBN 019-928857-7)

10. Uemichi A, Kanetsuki I, Kaneko S (2017) Combustion oscillation in gas turbine combustor for fuel mixture of hydrogen and natural gas. In: ASME 2017 pressure vessels and piping conference, PVP 2017 - Waikoloa, United States. https://doi. org/https://doi.org/10.1115/PVP2017-65692

11. World Heritage Encyclopedia (2020) Flammability Limits. Project Gutenberg Self-Publishing Press. Flammability Section. http://self.gutenberg.org/articles/Flammability_limits

12. Rumsey $C L$ (2015) Turbulence Modeling Verification and Validation (Invited). NASA Langley Research Centre, Hampton, VA 23681-2199, USA. P 5 of 13. Downloaded on 19 February 2020. https://ntrs.nasa.gov/archive/nasa/casi.ntrs.nasa.gov/20140 003976.pdf

13. Support \& Learning - AUTODESK (2020) SST K-Omega Turbulence Models. Autodesk Inc. USA. Dditinal Notes about SST k-omega section

14. Ghiaasiaan SM (2012) Convective heat and mass transfer. Cambridge University Press, Cambridge, pp 470-479 (ISBN 9780511800603)

15. Andersson $B$, Andersson $R$, Hakansson $L$, Mortensen $M$, Sudiyo R, Van-Wachem B (2012) Computational fluid dynamics for 
engineers. Cambridge University Press, Cambridge, pp 94, 100, 114, 136 and 175 (ISBN 9780511800603 )

16. Braunling WJG (2013) Flugzeugtriebwerke: grundlagen, aerothermodynamik, kreisprozesse, thermische turbomaschinen, komponenten-und auslegungsberechnungen. Springer , Berlin , p 764 (ISBN: 9783662072707)

17. Lee H-H (2019) Finite element simulations with ANSYS workbench 2019-theory, applications, case studies. Published by SDC. (ISBN: 978-1-63057-299-0). Section 9.3.

18. Dean AJ, Penyazkov OG, Sevruk KL, Varatharajan B (2007) Autoignition of surrogate fuels at elevted temperatures and pressures. In: Proceedings of the Combstion Institute. Publisher Elsevier. Absract section. https://doi.org/https://doi.org/ 10.1016/j.proci.2006.07.162

19. Kazi SN (2012) An overview of heat transfer phenomena. Rijeka, InTech, pp 132 \& 479 (ISBN 978-953-51-0827-6)
20. Yang J, Wu X-y, Wang Z-g (2016) Parametric study of fuel distribution effects in kerosene based scramjet combustor. Int J Aerosp Eng. Hindawi Open Acess Publishing. http://downl oads.hindawi.com/journals/ijae/2016/7604279.pdf. p 2

21. Caton PA, Hamilton LJ, Cowart JS (2011) Understanding ignition delay effects with pure component fuels in a single-cylinder diesel engine. J Eng Gas Turbines Power Doi 10(1115/1):4001943

22. Propane Gas Properties (2020) Gas Encyclopedia. AIR LIQUIDE. https://Encyclopedia.airliquide.com/Propane

23. Massey B, Ward-Smith J (2006) Mechanics of fluids. Milton Park, Taylor \& Francis Group, p 669 (ISBN 0-415-36206-7)

Publisher's Note Springer Nature remains neutral with regard to jurisdictional claims in published maps and institutional affiliations. 